\title{
VEHICLE ROUTING PROBLEM - CASE STUDY ON LOGISTICS COMPANY IN CROATIA
}

\author{
Martina Jakara ${ }^{1}$, Jasmina Pašagić Škrinjar ${ }^{2}$, Nikolina Brnjac ${ }^{3}$ \\ ${ }_{1,2,3}$ University of Zagreb, Faculty of Transport and Traffic Sciences, Zagreb, Croatia
}

Received 6 June 2019; accepted 20 September 2019

Abstract: This paper defines the vehicle routing problem that logistic operators and other traffic professionals face in organizing transportation and determining the optimal routes and number of vehicles needed to provide a quality transport service. The purpose of the paper is to outline the methods used to solve the problem and to compare their application. This example shows the application of metaheuristic methods for solving vehicle routing problems of a logistics company in the Republic of Croatia. The aim of this case study is to determine the optimal solution using methods which represents such a distribution of available vehicles that generates the lowest cost.

Keywords: transport logistics, transport networks, mathematical methods, optimization, heuristics, metaheuristics, vehicle routing.

\section{Introduction}

Realization of technological processes is one of the most important elements of decision making. Three levels of decision making can be analyzed in transportation: strategic, tactical and operational level. At the strategic level, a decision is made to determine the warehouse location. The choice of traffic mode and type of transport vehicle is made at the tactical level. At the operational level, optimal routes are chosen for vehicles selected at the tactical level and based on the location of the warehouse at the strategic level. The transport problem is the problem of determining the transport schedule of a particular transport substrate from the source to the destinations whose substrate demand is to be met, using the available transport routes by the criterion of minimum transport cost or shortest transport route.
The problem of determining optimal routes for a group of vehicles in the literature has been described as a Vehicle Routing Problem (VRP). There are many different mathematical models and algorithms for solving this problem.

The purpose of this paper is to demonstrate the application of mathematical methods for solving vehicle routing problem. After analyzing the transport network of the logistics company, a mathematical model of the vehicle routing problem was optimized using the Nearest Neighbor Heuristics and the VRP Spreadsheet Solver optimization program, which combines different heuristic methods to solve previously mentioned problem. The main goal of this paper is to determine the optimal solution for distribution of available vehicles with the lowest cost and to explain the results and the

${ }^{1}$ Corresponding author: mjakara@fpz.hr 
difference in the application after comparing the applied methods. This paper presents the determination of the transport plan in the transport network of the observed enterprise. The organization of vehicle routing will be carried out in the city of Zagreb by example of deliveries for Monday and Wednesday.

\section{Vehicle Routing Problem}

A key element in the logistics chain is the transportation system. As transport costs account for the largest share of total logistics costs, improving transport efficiency has a significant impact on increasing the overall performance of the logistics chain, thereby directly affecting the results of logistics activities. Transportation costs vary depending on different industries (Pavlić Skender and Grčić Fabić, 2013). They depend on fuel prices and often exceed $50 \%$ of total logistics costs. It is necessary to reduce the share of logistics costs in the total costs of certain products or services, which can be achieved by solving the appointed transport problem. By analyzing the transport network and identifying existing shortcomings and bottlenecks, it is possible to set up a transport problem and solve it with mathematical methods such as heuristics or mathematical models, which are reducing the number of vehicles and costs of distribution by optimizing other elements of the transport network. Solving the transport problem determines the optimal transportation schedule, which implies a plan of transportation of goods, which from the point of origin to the destination has the minimum total transportation costs (Pašagić, 2003).

The transport network can be defined as a system of interconnected and interest connected transport hubs, roads, corridors, routes, lines, transport chains that enable fast, safe and rational processes of production of transport services. The purpose of transport networks is to transport certain goods, materials or passengers from one place to another. The basic elements of a transport network are nodes and links. A node is a place or point of loading where loading/unloading, sorting, storage and change of transport vehicle or mode of transport take place. Links represent transport and transport activities that connect nodes, creating a transport network. By connecting all source and destination nodes with a sufficient number of transshipment nodes, a transport network is obtained (Woxenius, 1998; Woxenius, 1997). The transport network is a complex system and it is therefore not surprising that it has various problems. The resulting problems need to be optimized to maximize the utilization of the transport network and to make transport processes more efficient. The commitment to these issues is extremely high, and with the development of logistics and computer technology has become even greater. Therefore, various mathematical methods and programming tools are being used today to optimize the problems encountered on the transport network. Some of the problems that arise on the transportation network are transportation problems, the shortest route problem, the vehicle routing problem, location problems, the traveling salesman problem and many others (Buntak et al., 2013).

One of the prominent problems in logistics is the Vehicle Routing Problem (VRP). The problem of routing vehicles requires finding the optimal route from the initial terminal to all the designated destinations in such a way that demand at the destinations is satisfied and the total distance traveled by the delivery vehicles is minimized (Dantzig 
and Ramser, 1959). The classic problem of routing a vehicle is to find a series of routes with minimal cost (finding the shortest route, minimizing the number of vehicles, etc.) starting and ending routes at the source, so that the demand of all destinations is met (Belfiore and Yoshizaki, 2009). VRP is a generic name for a series of problems that arise when distributing goods, where it is necessary to determine the route by which a vehicle will tour a certain number of cities at a minimum total cost and in the shortest possible time. Vehicle Routing Problem is defined as a number of vehicles with a given capacity. Each customer order has a specific location and size. There are default shipping costs between all locations. The goal is to design an optimal itinerary so that all customers are visited once and capacity constraints are met. Troubleshooting involves finding the optimal sequence of visiting locations, provided that only one vehicle is served by each location. The limitation of the set condition is that the total demand of all users on a particular route does not exceed the capacity of the vehicle (Hasle and Kloster, 2007). VRP can be described as the problem of designing optimal delivery or collection routes from one or more warehouses to a number of geographically dispersed entities (cities or users) that are subject to additional restrictions (Toth and Vigo, 2002). It is about the distribution of goods over a given time, a certain number of users, a certain number of vehicles that are housed in one or more warehouses. The vehicles are moving along the default transport network. Typically, the solution to this problem is to find routes, where each route is driven by one vehicle starting from the original warehouse and returning to it, all set limits must be met and the total cost of the transportation (distance traveled by vehicles) must be kept to a minimum
(Čolić, 2013). Depending on the constraints a route has, there are several types of routing problems.

According to (Laporte, 2007), every form of VRP requires equal resolution, which is to serve all users under the following restrictions:

1. each route starts and ends at the warehouse;

2. each user is visited exactly once;

3. the total demand of each route does not exceed the capacity of the vehicle.

The optimal solution to a particular problem solving is usually attempted by mathematical methods. In problems where the input data are not constants but depend on time or some stochastic factor, it is not possible to construct a representative mathematical model. Sometimes, due to the complexity of the data and the problem size, the mathematical model provides the optimal solution but in a extremely long period of time. Heuristic methods help to arrive at a solution in a short time that may not be optimal but close to optimal. Heuristic methods can be divided into special and general heuristics. Specials are designed for special types of optimization problems while respecting their characteristics and their special features. General heuristics, often referred as metaheuristics, are generalpurpose methods that can be applied to any combinatorial optimization problem, regardless of the specifics of its structure (Stanković and Pašagić Škrinjar, 2015).

The Nearest Neighbor Heuristics (NNH) is one of the first algorithms to solve vehicle routing problems and is often used as an initial solution for testing repair heuristics. It's pretty fast, but the solutions are almost always far from optimal. The $\mathrm{NNH}$ 
algorithm works by randomly selecting a starting city from a set of cities, adding it to a route and marking it as a visited. Then, from a set of unvisited cities, the algorithm finds the closest city from the previously added one and adds it to the route which indicates that the city has been visited. This step is repeated until all cities are visited (Carić, 2004).

Metaheuristics-based software tools provide quick solutions that are very close to optimal solutions. Algorithms using exact mathematical methods require a long-term process to solve, which is not appropriate in the field of logistics since it is necessary to respond to customer requests as soon as possible. Heuristic models are much more applicable than exact mathematical models in solving problems with variables (eg. changes in infrastructure capacity over time, changes in prices, etc.). The VRP Spreadsheet Solver program was created using this approach, in which is possible to set up, solve and visualize the results of vehicle routing problem (VRP). The above program combines Excel, public GIS and metaheuristics. It can solve over 64 variants of VRP's with up to 200 users (Erdoğan, 2017). Among these are the problems mentioned earlier, including limitations on capacity, distance, time, simultaneous delivery and collection, delivery and collection of returned goods. The advantage of this tool is that it's simple, practical and easy to use. Because the program is refined with a metaheuristic approach, it has implemented an algorithm based on Large Neighborhood Search (LNS). The strategy is to try capturing the widest possible solution spaces during the search and to explore only those areas that promise to find quality solutions (Galić, 2018).

\section{Optimal Solution of the Vehicle Routing Problem}

In this chapter, the real-world example of routing a real logistics business is the application of metaheuristics in solving vehicle routing problems. The observed company collects goods from a destination in the city of Zagreb and transports them to its warehouse. This example shows the organization and optimization of daily routes for Monday and Wednesday. For Monday, ten destinations were defined, while eight destinations were defined on Wednesday. Using the coordinates of the source location and all destinations, a matrix for the distances between all locations was made for both days, and the displayed matrices were asymmetric (two-way). This way of making the matrix is more accurate for deliveries in the city of Zagreb because of the large number of one-way roads that significantly affect the difference in distance in two directions between two points. Metaheuristic methods will determine the optimal number of vehicles and the shortest routes for each vehicle to minimize the final distribution cost. The Nearest Neighbor method and the VRP Spreadsheet Solver program described in the previous section are used to resolve vehicle routing problem. The type of goods being transported is liquid cargo stored in barrels. Each barrel occupies a cargo area of $0,16 \mathrm{~m}^{2}$ (dimensions $40 \times 40 \mathrm{~cm}$ ). The weight of one barrel is 37 kilograms. The barrels are constructed that they can be stacked on top of each other in height. In the example, a profit of $70 \mathrm{HRK}(9,46 \mathrm{EUR})$ will be used for each barrel collected. Values in EUR are obtained by dividing the HRK values by 7,4, which was the average of the HRK/EUR ratio in September 2019. 
Delivery vehicle used for city distribution is a small truck in third category of the Iveco brand, from which it can be concluded that this is a homogeneous problem of routing the vehicle. The maximum load capacity is 2,2 tons and the volume of cargo space is $16 \mathrm{~m}^{3}$. The vehicle has diesel powered engine and uses 16 liters / 100 kilometers for city driving. Diesel fuel price on the day $19^{\text {th }}$ of February, 2019 amounted 9,65 HRK (1,3 EUR) per liter from which it can be calculated that the cost of transport per kilometer for this vehicle is $1,544 \operatorname{HRK}(0,21$ EUR)/ km (9,65 HRK x 16/100).

With a maximum mass limit, a maximum of 55 barrels $(2200 \mathrm{~kg} / 37 \mathrm{~kg})$ can be loaded into one vehicle. There are 36 barrels on one level in the cargo area and given that they can be stacked in several rows, it is concluded that the limiting factor in this case is mass.

\subsection{First Case of Delivery Optimization - Monday}

The first example that will show the application of heuristics is the schedule of delivery destinations and delivery vehicles in the city of Zagreb for Monday. Table 1 shows the locations of the source and the ten destinations to be visited on a given day. Pickup amount of each destination is also shown in the table. Pickup amount is important in routing the vehicles because of the limited capacity of the vehicle itself.

Table 1

Locations and Pickup Amount at Monday Destinations

\begin{tabular}{|l|c|c|}
\hline \multicolumn{1}{|c|}{ Node } & Location ID & Pickup amount \\
\hline The source location & I & 0 \\
\hline Destination 1 & D1 & 4 \\
\hline Destination 2 & D2 & 6 \\
\hline Destination 3 & D3 & 11 \\
\hline Destination 4 & D4 & 13 \\
\hline Destination 5 & D5 & 20 \\
\hline Destination 6 & D6 & 17 \\
\hline Destination 7 & D7 & 11 \\
\hline Destination 8 & D8 & 9 \\
\hline Destination 9 & D9 & 12 \\
\hline Destination 10 & D10 & 8 \\
\hline
\end{tabular}

The distance matrix in kilometers is shown in Table 2. The distances shown in the table will be used to further calculate and resolve vehicle routing problem. 


\section{Table 2}

First case Distance Matrix - Monday

\begin{tabular}{|c|c|c|c|c|c|c|c|c|c|c|c|}
\hline & I & D1 & D2 & D3 & D4 & D5 & D6 & D7 & D8 & D9 & D10 \\
\hline I & 0,00 & 17,70 & 16,11 & 20,22 & 16,88 & 19,46 & 18,88 & 18,14 & 16,96 & 17,21 & 18,49 \\
\hline D1 & 16,72 & 0,00 & 4,13 & 4,71 & 4,05 & 9,27 & 11,72 & 10,04 & 9,49 & 8,75 & 6,77 \\
\hline D2 & 14,95 & 3,81 & 0,00 & 2,31 & 1,66 & 6,87 & 8,65 & 6,97 & 6,42 & 5,68 & 3,70 \\
\hline D3 & 15,98 & 4,49 & 2,37 & 0,00 & 0,62 & 5,53 & 7,29 & 5,61 & 5,07 & 4,33 & 2,33 \\
\hline D4 & 17,27 & 4,97 & 2,85 & 1,29 & 0,00 & 5,23 & 7,00 & 5,32 & 4,77 & 4,03 & 2,87 \\
\hline D5 & 19,91 & 8,55 & 6,43 & 4,06 & 4,68 & 0,00 & 1,88 & 2,83 & 2,89 & 3,38 & 4,98 \\
\hline D6 & 18,76 & 12,30 & 9,57 & 7,64 & 8,26 & 1,77 & 0,00 & 1,41 & 1,96 & 2,23 & 5,90 \\
\hline D7 & 18,25 & 10,34 & 7,62 & 5,19 & 5,81 & 1,92 & 1,65 & 0,00 & 1,45 & 1,72 & 5,40 \\
\hline D8 & 18,80 & 12,34 & 9,61 & 7,68 & 8,30 & 2,77 & 2,19 & 1,45 & 0,00 & 2,27 & 5,94 \\
\hline D9 & 18,05 & 8,97 & 6,24 & 4,09 & 4,71 & 1,96 & 3,06 & 1,69 & 1,14 & 0,00 & 3,20 \\
\hline D10 & 17,00 & 6,39 & 3,67 & 1,74 & 2,36 & 4,57 & 6,34 & 4,66 & 4,11 & 3,37 & 0,00 \\
\hline
\end{tabular}

\subsubsection{Resolving the Vehicle Routing Problem for Monday with the Nearest Neighbor Heuristics}

As noted above, the Nearest Neighbor Heuristics starts from the source and searches for the nearest destination to set it as the first destination. After arriving at the first destination, it re-searches for the closest un-visited destination in second iteration and sets it as the second destination. This process is repeated until all destinations are visited and the vehicle is returned to its source location. Given that there is also a capacity limit in this case, it is necessary to set the pickup amount 0 at source and add it to the pickup amount of each destination visited. The last destination before exceeding the permitted vehicle capacity is set as the last destination for that vehicle and returns to the source after visiting it.
According to the matrix in Table 2, the minimum distance of $16,11 \mathrm{~km}$ is between the source and Destination 2. Destination 2 has a pickup amount of 6 barrels, which increases the initial capacity of the vehicle from 0 to current 6 . From Destination 2, the nearest unvisited neighbor is again searched for and that is Destination 4 which is 1,66 $\mathrm{km}$ away with a pickup amount of 13 barrels. The capacity rate is increasing to 19 . The next destination is Destination 3 which is $1,29 \mathrm{~km}$ from Destination 4. Filled capacity at Destination 3 is increasing to 30 barrels from the maximum 55. Next location is Destination 10, 2,33 km away and the capacity is being filled to 38 barrels. The next closest undisclosed location is Destination 9 at $3,37 \mathrm{~km}$, which has a pickup amount of 12 barrels. This fills the maximum capacity of the delivery vehicle which returns to source after Destination 9 by crossing $18,05 \mathrm{~km}$. The route of the first vehicle is shown in Figure 1. 


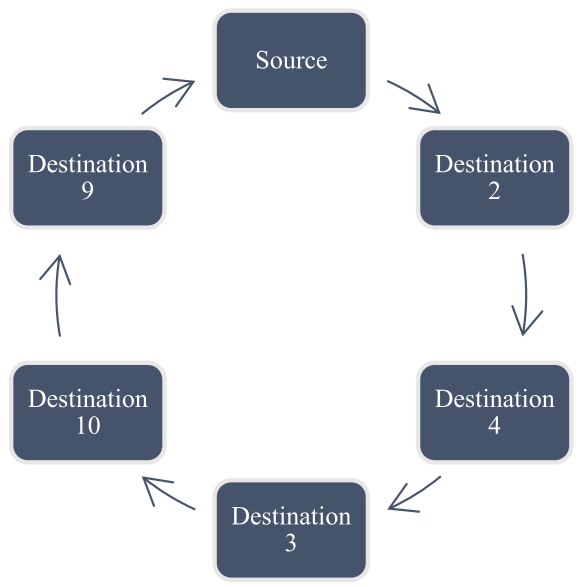

Fig. 1.

Route of the First Vehicle by the Nearest Neighbor Heuristics - Monday

The second vehicle re-starts from the source and visits the nearest unvisited neighbor. This is Destination 8 distant 16,96 $\mathrm{km}$ away from the source. The pickup amount at Destination 8 is 9 barrels. From Destination 8 , the closest unattended destination is Destination 7 which is $1,45 \mathrm{~km}$ away with 11 barrels in pickup amount. Following is Destination 6 in distance $1,65 \mathrm{~km}$ away with a pickup amount of 17 barrels. The total capacity occupancy of the vehicle is 37 and the remaining destinations are in greater pickup amount than can be loaded into another vehicle, so the vehicle after Destination 6 returns to source location by passing $18,76 \mathrm{~km}$.

There is only Destination 5 left to visit for this heuristic, with a pickup amount of 20 barrels. So the third vehicle from source to Destination 5 will make 19,46 km, and 19,91 $\mathrm{km}$ back to source location. Table 3 shows the routes for all engaged vehicles according to the specified method.

Table 3

Preview of the Routes of all Delivery Vehicles Hired on Monday According to the Nearest Neighbor Heuristics

\begin{tabular}{|l|c|}
\hline First vehicle & I-D2 - D4 - D3 - D10 - D9-I \\
\hline Second vehicle & I - D8 - D7 - D6-I \\
\hline Third vehicle & I - D5 - I \\
\hline
\end{tabular}


After the Nearest Neighbor Heuristics has determined all routes and the number of vehicles required to serve all destinations, the cost of shipping costs will be shown below. The total net profit of the deliveries made is calculated by reducing the transport costs from the profit of the total number of freight collected. It can be seen in Table 1 that the total number of barrels collected is 111 , which multiplied by $70 \mathrm{HRK}(9,46$ EUR) per barrel gives a profit of 7.770,00 HRK (1050 EUR). If you add up all the kilometers traveled, all three used vehicles give you a number of $121 \mathrm{~km}$, which according to the fuel price calculation at the beginning of the chapter multiplies by 1,544 HRK $(0,21$ EUR). The total cost of delivery is $186,82 \mathrm{HRK}(25,22 \mathrm{EUR})$ and when this is deducted from the profit obtained, it can be concluded that the Nearest Neighbor Heuristics generated a net profit of 7.583,66 HRK (1.024,82 EUR).

\subsubsection{Resolving the Vehicle Routing Problem for Monday with the VRP Spreadsheet Solver Optimization Program}

According to the Monday delivery data shown in Table 1, a problem has been previewed in the VRP Spreadsheet Solver optimization program, which solves the metaheuristic principle of vehicle routing and offers an optimal solution. In this example, there are one source and ten destinations. The number of vehicle types is determined, which in this case is one. It is also shown that all vehicles must be returned to the source.

After the first worksheet, a second worksheet is created which is called 1 . Locations. The locations with corresponding pickup amounts are shown in Table 1 at the beginning of the description of the first case. In addition to the information in Table 1, the coordinates of each location that were collected from the Google Maps page are written on the worksheet for the purpose of automatically calculating distances between locations. The following worksheet is 2 . Distances, showing the distance matrix between all locations and the travel time between nodes. The following worksheet sets out delivery truck information. In this example, a type of Iveco truck with a total capacity of 2,2 tones was installed. The capacity of 55 barrels and a unit shipping cost of $1,544 \mathrm{HRK}(0,21$ EUR) per kilometer are defined at the beginning of the chapter. The required number of vehicles is set to 3 in the analysis because a smaller number of vehicles does not meet the capacity limit, while a larger number of vehicles is not needed because the three vehicles generate the lowest costs. After this worksheet, a solution worksheet is set up, which is shown in Table 4. Table 4 shows the number of stops and the profit generated for each vehicle, where each destination shows the time of arrival and departure, retention time, realized profit and the amount of cargo collected. 
Table 4

Preview the Vehicle Routing for Monday Obtained using the VRP Spreadsheet Solver

\begin{tabular}{|c|c|c|c|c|c|c|c|c|}
\hline \multirow{3}{*}{$\begin{array}{l}\text { Vehicle: } \\
\begin{array}{l}\text { Location } \\
\text { name }\end{array} \\
\end{array}$} & \multirow{3}{*}{\begin{tabular}{|l}
$\mathrm{V} 1$ \\
$\begin{array}{l}\text { Distance } \\
\text { travelled }\end{array}$ \\
\end{tabular}} & \multirow{3}{*}{$\begin{array}{l}\text { Stops: } \\
\text { Driving } \\
\text { time }\end{array}$} & \multirow{3}{*}{\begin{tabular}{|l}
5 \\
$\begin{array}{l}\text { Arrival } \\
\text { time }\end{array}$ \\
\end{tabular}} & \multirow{3}{*}{$\begin{array}{l}\text { Net } \\
\text { profit: } \\
\begin{array}{l}\text { Departure } \\
\text { time }\end{array} \\
\end{array}$} & \multicolumn{3}{|c|}{ 2318,26 HRK (321,79 EUR) } & \multirow{3}{*}{ Load } \\
\hline & & & & & \multirow{2}{*}{$\begin{array}{l}\text { Working } \\
\text { time }\end{array}$} & \multicolumn{2}{|c|}{ Profit collected } & \\
\hline & & & & & & HRK & EUR & \\
\hline $\begin{array}{l}\text { The source } \\
\text { location }\end{array}$ & 0,00 & $0: 00$ & & 08:00 & 0:00 & 0 & 0 & 0 \\
\hline Destination 1 & 17,70 & $0: 32$ & $08: 32$ & $08: 46$ & $0: 46$ & 280 & 37,84 & 4 \\
\hline Destination 2 & 21,23 & $0: 44$ & 08:58 & 09:14 & $1: 14$ & 700 & 94,59 & 10 \\
\hline Destination 4 & 22,89 & $0: 50$ & 09:20 & $09: 43$ & $1: 43$ & 1610 & 217,57 & 23 \\
\hline Destination 3 & 24,01 & $0: 54$ & 09:47 & $10: 08$ & 2:08 & 2380 & 321,62 & 34 \\
\hline $\begin{array}{l}\text { The source } \\
\text { location }\end{array}$ & 39,99 & $1: 24$ & $10: 38$ & & $2: 38$ & 2380 & 321,62 & 34 \\
\hline
\end{tabular}

\begin{tabular}{|c|c|c|c|c|c|c|c|c|}
\hline \multirow{3}{*}{$\begin{array}{l}\text { Vehicle: } \\
\begin{array}{l}\text { Location } \\
\text { name }\end{array}\end{array}$} & \multirow{3}{*}{$\begin{array}{l}\text { V2 } \\
\text { Distance } \\
\text { travelled }\end{array}$} & \multirow{3}{*}{$\begin{array}{l}\text { Stops: } \\
\begin{array}{l}\text { Driving } \\
\text { time }\end{array}\end{array}$} & \multirow{3}{*}{\begin{tabular}{|l|}
4 \\
$\begin{array}{l}\text { Arrival } \\
\text { time }\end{array}$ \\
\end{tabular}} & \multirow{3}{*}{\begin{tabular}{l|} 
Net \\
profit: \\
Departure \\
time
\end{tabular}} & \multicolumn{3}{|c|}{ 3297,72 HRK (445,64 EUR) } & \multirow{3}{*}{ Load } \\
\hline & & & & & \multirow{2}{*}{$\begin{array}{l}\text { Working } \\
\text { time }\end{array}$} & \multicolumn{2}{|c|}{ Profit collected } & \\
\hline & & & & & & HRK & EUR & \\
\hline $\begin{array}{l}\text { The source } \\
\text { location }\end{array}$ & 0,00 & $0: 00$ & & 08:00 & $0: 00$ & 0 & 0 & 0 \\
\hline Destination 7 & 18,14 & $0: 34$ & $08: 34$ & $08: 55$ & $0: 55$ & 770 & 104,05 & 11 \\
\hline Destination 5 & 19,70 & $0: 43$ & 09:04 & $09: 34$ & $1: 34$ & 2170 & 293,24 & 31 \\
\hline Destination 6 & 21,58 & $0: 55$ & $09: 46$ & $10: 13$ & $2: 13$ & 3360 & 454,05 & 48 \\
\hline $\begin{array}{l}\text { The source } \\
\text { location }\end{array}$ & 40,34 & $1: 25$ & $10: 43$ & & $2: 43$ & 3360 & 454,05 & 48 \\
\hline
\end{tabular}

\begin{tabular}{|c|c|c|c|c|c|c|c|c|}
\hline \multirow{3}{*}{$\begin{array}{l}\text { Vehicle: } \\
\begin{array}{l}\text { Location } \\
\text { name }\end{array}\end{array}$} & \multirow{3}{*}{$\begin{array}{l}\text { V3 } \\
\text { Distance } \\
\text { travelled }\end{array}$} & \multirow{3}{*}{\begin{tabular}{|l|} 
Stops: \\
$\begin{array}{l}\text { Driving } \\
\text { time }\end{array}$ \\
\end{tabular}} & \multirow{3}{*}{$\begin{array}{l}4 \\
\text { Arrival } \\
\text { time }\end{array}$} & \multirow{3}{*}{\begin{tabular}{l|}
$\begin{array}{l}\text { Net } \\
\text { profit: }\end{array}$ \\
Departure \\
time
\end{tabular}} & \multicolumn{3}{|c|}{1971,03 (266,36 EUR) } & \multirow{3}{*}{ Load } \\
\hline & & & & & \multirow{2}{*}{$\begin{array}{l}\text { Working } \\
\text { time }\end{array}$} & \multicolumn{2}{|c|}{ Profit collected } & \\
\hline & & & & & & HRK & EUR & \\
\hline $\begin{array}{l}\text { The source } \\
\text { location }\end{array}$ & 0,00 & $0: 00$ & & 08:00 & 0:00 & 0 & 0 & 0 \\
\hline Destination 8 & 16,96 & $0: 27$ & $08: 27$ & 08:46 & $0: 46$ & 630 & 85,14 & 9 \\
\hline Destination 9 & 19,22 & $0: 34$ & $08: 53$ & $09: 15$ & $1: 15$ & 1470 & 198,65 & 21 \\
\hline Destination 10 & 22,43 & $0: 46$ & $09: 27$ & $09: 45$ & $1: 45$ & 2030 & 274,32 & 29 \\
\hline $\begin{array}{l}\text { The source } \\
\text { location }\end{array}$ & 38,19 & $1: 15$ & $10: 14$ & & $2: 14$ & 2030 & 274,32 & 29 \\
\hline
\end{tabular}

The total net profit gained by this method of routing is 7.587,01 HRK (1.025,27 EUR). The routes obtained by the optimization program are displayed on the last worksheet. 
3.2. Second Case of Delivery Optimization

\section{- Wednesday}

The second example that will show the application of metaheuristics is the schedule of delivery locations and delivery vehicles in the Zagreb area for Wednesday. Table 5 shows the source and the eight destinations to be visited on a given day and their pickup amount in the number of barrels to be collected.

\section{Table 5}

Locations and Pickup Amount at Destinations for Wednesday

\begin{tabular}{|c|c|c|}
\hline Node & Location ID & Pickup amount \\
\hline The source location & I & 0 \\
\hline Destination 1 & D1 & 30 \\
\hline Destination 2 & D2 & 27 \\
\hline Destination 3 & D3 & 21 \\
\hline Destination 4 & D4 & 18 \\
\hline Destination 5 & D5 & 24 \\
\hline Destination 6 & D6 & 33 \\
\hline Destination 7 & D7 & 23 \\
\hline Destination 8 & D8 & 22 \\
\hline
\end{tabular}

The distance matrix in kilometers is shown in Table 6. The distances shown in the table will be used to further calculate and resolve the vehicle routing problem.

\section{Table 6}

Distance Matrix for the Second Case - Wednesday

\begin{tabular}{|c|c|c|c|c|c|c|c|c|c|}
\hline & I & D1 & D2 & D3 & D4 & D5 & D6 & D7 & D8 \\
\hline I & 0,00 & 17,77 & 16,93 & 16,99 & 22,82 & 17,48 & 22,09 & 21,96 & 19,63 \\
\hline D1 & 20,49 & 0,00 & 2,04 & 1,55 & 6,59 & 3,67 & 7,86 & 11,61 & 3,82 \\
\hline D2 & 18,28 & 2,26 & 0,00 & 0,78 & 4,29 & 1,47 & 5,62 & 5,53 & 3,17 \\
\hline D3 & 18,15 & 1,86 & 1,41 & 0,00 & 5,70 & 2,88 & 7,03 & 10,77 & 3,61 \\
\hline D4 & 21,52 & 7,19 & 4,89 & 5,71 & 0,00 & 3,73 & 2,74 & 4,35 & 10,02 \\
\hline D5 & 18,23 & 3,49 & 1,22 & 2,00 & 3,35 & 0,00 & 4,62 & 4,50 & 2,54 \\
\hline D6 & 20,95 & 6,30 & 4,41 & 5,18 & 1,76 & 3,15 & 0,00 & 1,52 & 4,49 \\
\hline D7 & 22,34 & 12,03 & 10,59 & 10,88 & 3,15 & 4,54 & 3,10 & 0,00 & 8,02 \\
\hline D8 & 20,50 & 4,02 & 2,71 & 3,00 & 5,11 & 2,74 & 8,57 & 7,16 & 0,00 \\
\hline
\end{tabular}

\subsubsection{Resolving the Vehicle Routing Problem for Wednesday with the Nearest Neighbor Heuristics}

According to the matrix in Table 6, the shortest distance from the source is to Destination 2 in amount of $16,93 \mathrm{~km}$. Destination 2 has a pickup amount of 27 barrels, increasing the initial capacity occupancy of the vehicle from 0 to the current 27. From Destination 2, the closest unvisited neighbor is searched for and it can be seen that Destination 3 is $0,78 \mathrm{~km}$ away with a pickup amount of 21 barrels. Capacity is increased to 49 , which re-routs this vehicle by returning it $18,15 \mathrm{~km}$ to its source. 
Second vehicle re-starts from the source and visits the nearest unvisited neighbor. This is Destination 5, which is $17,48 \mathrm{~km}$ away from the source. Pickup amount at Destination 5 is 24 barrels. From Destination 5, the closest unvisited destination is Destination 8, 2,54 $\mathrm{km}$ away with 22 barrels in pickup amount. The total capacity of the vehicle is 46 and the remaining destinations have greater pickup amount than can be loaded into this vehicle, so that the vehicle returns $20,50 \mathrm{~km}$ to its source after Destination 8.

The next closest unvisited destination they are looking at from the source is Destination 1 , which is $17,77 \mathrm{~km}$ away and has a pickup amount of 30 barrels. From Destination 1, out of the three remaining destinations, Destination 4 is $6,59 \mathrm{~km}$ away with a pickup amount of 18 barrels. The remaining capacity is not sufficient for further loading and the third vehicle returns to the source distant $21,52 \mathrm{~km}$.

The remaining two destinations cannot be combined into one vehicle because pickup amount exceeds the capacity of the vehicle, so each will need to be delivered with one vehicle. Destination 7 has a pickup amount of 23 barrels. So the fourth vehicle will make $21,96 \mathrm{~km}$ from Source location to Destination 7 , and back $22,34 \mathrm{~km}$ to the source.

The fifth vehicle is the last from the source travels 22,09 km to Destination 6 and 20,95 $\mathrm{km}$ back to the source. Pickup amount at Destination 6 is 33 barrels. Table 7 shows the routes of all vehicles engaged for Wednesday.

Table 7

Preview of the Routes of all Delivery Vehicles Engaged on Wednesday Using the Nearest Neighbor Heuristics

\begin{tabular}{|l|c|}
\hline First vehicle & I - D2 - D3 - I \\
\hline Second vehicle & I - D5 - D8 - I \\
\hline Third vehicle & I - D4 - D1 - I \\
\hline Fourth vehicle & I - D7 - I \\
\hline Fifth vehicle & I - D6 - I \\
\hline
\end{tabular}

After the Nearest Neighbor Heuristics has determined all the routes and the required number of vehicles, it is necessary to make a calculation of the delivery costs. The total net profit of the deliveries made is calculated by deducting the transport costs from the profit of the total number of freight collected. It can be seen from Table 4 that the total number of barrels collected is 198 , which multiplied by $70 \mathrm{HRK}(9,46 \mathrm{EUR})$ per barrel gives a profit of 13.860,00 HRK (1872,97 EUR). If all kilometers of all five vehicles are summed up, the amount number is $209,6 \mathrm{~km}$, which is multiplied by $1,544 \mathrm{HRK}(0,21 \mathrm{EUR})$ at the beginning of the chapter according to the fuel price calculation. The total cost of delivery is $323,62 \mathrm{HRK}(43,73 \mathrm{EUR})$ and when this is deducted from the profit received, it can be concluded that application of the Nearest Neighbor Heuristics in the delivery for Wednesday resulted in a net profit of 13.536,38 HRK (1.829,24 EUR).

\subsubsection{Resolving the Vehicle Routing Problem for Wednesday with the VRP Spreadsheet Solver Optimization Program}

According to the Wednesday delivery locations shown in Table 5, a problem has been defined in VRP Spreadsheet Solver optimizer program. As in the Monday optimization example, the first worksheet specifies 
the number of sources and the number of destinations to be served. In this example, there is one source and eight destinations. The number of vehicle types is determined, which in this case is one. It also specifies the condition that all vehicles must be returned to the source. The procedure for creating worksheets is the same as in the previous case for Monday, except that the required number of vehicles by analysis is set to four because a smaller number of vehicles does not meet the capacity limit. While a larger number of vehicles is not needed as four vehicles generate the lowest costs. After this worksheet, a solution worksheet is set up which is shown in Table 8. Using the VRP Spreadsheet Solver optimization software, a total net profit of 13.601,17 HRK (1.838 EUR) was obtained.

\section{Table 8}

Preview of Vehicle Routing for Wednesday Obtained with VRP Spreadsheet Solver

\begin{tabular}{|c|c|c|c|c|c|c|c|c|}
\hline \multirow{3}{*}{\begin{tabular}{|l} 
Vehicle: \\
$\begin{array}{l}\text { Location } \\
\text { name }\end{array}$
\end{tabular}} & \multirow{3}{*}{\begin{tabular}{|l|} 
V1 \\
$\begin{array}{l}\text { Distance } \\
\text { travelled }\end{array}$ \\
\end{tabular}} & \multirow{3}{*}{\begin{tabular}{|l} 
Stops: \\
$\begin{array}{l}\text { Driving } \\
\text { time }\end{array}$
\end{tabular}} & \multirow{3}{*}{\begin{tabular}{|l}
3 \\
$\begin{array}{l}\text { Arrival } \\
\text { time }\end{array}$
\end{tabular}} & \multirow{3}{*}{\begin{tabular}{|l}
$\begin{array}{l}\text { Net } \\
\text { profit: }\end{array}$ \\
$\begin{array}{l}\text { Departure } \\
\text { time }\end{array}$
\end{tabular}} & \multicolumn{3}{|c|}{ 3575,01 HRK (483,11 EUR) } & \multirow{3}{*}{ Load } \\
\hline & & & & & \multirow{2}{*}{$\begin{array}{l}\text { Working } \\
\text { time }\end{array}$} & \multicolumn{2}{|c|}{ Profit collected } & \\
\hline & & & & & & HRK & EUR & \\
\hline $\begin{array}{l}\text { The source } \\
\text { location }\end{array}$ & 0,00 & $0: 00$ & & 08:00 & $0: 00$ & 0 & 0 & 0 \\
\hline Destination 1 & 17,77 & $0: 35$ & $08: 35$ & $08: 45$ & $0: 45$ & 2100 & 283,78 & 30 \\
\hline Destination 8 & 21,59 & $0: 46$ & $08: 56$ & 09:06 & $1: 06$ & 3640 & 491,89 & 52 \\
\hline $\begin{array}{l}\text { The source } \\
\text { location }\end{array}$ & 42,09 & $1: 32$ & 09:52 & & $1: 52$ & 3640 & 491,89 & 52 \\
\hline
\end{tabular}

\begin{tabular}{|c|c|c|c|c|c|c|c|c|}
\hline \multirow{3}{*}{$\begin{array}{l}\text { Vehicle: } \\
\text { Location } \\
\text { name }\end{array}$} & \multirow{3}{*}{\begin{tabular}{|l|}
$\mathrm{V} 2$ \\
$\begin{array}{l}\text { Distance } \\
\text { travelled }\end{array}$
\end{tabular}} & \multirow{3}{*}{$\begin{array}{l}\text { Stops: } \\
\begin{array}{l}\text { Driving } \\
\text { time }\end{array}\end{array}$} & \multirow{3}{*}{$\begin{array}{l}3 \\
\begin{array}{l}\text { Arrival } \\
\text { time }\end{array}\end{array}$} & \multirow{3}{*}{$\begin{array}{l}\text { Net } \\
\text { profit: } \\
\begin{array}{l}\text { Departure } \\
\text { time }\end{array}\end{array}$} & \multicolumn{3}{|c|}{ 3304,63 HRK ( 446,57 EUR) } & \multirow{3}{*}{ Load } \\
\hline & & & & & \multirow{2}{*}{$\begin{array}{l}\text { Working } \\
\text { time }\end{array}$} & \multicolumn{2}{|c|}{ Profit collected } & \\
\hline & & & & & & HRK & EUR & \\
\hline $\begin{array}{l}\text { The source } \\
\text { location }\end{array}$ & 0,00 & $0: 00$ & & 08:00 & $0: 00$ & 0 & 0 & 0 \\
\hline Destination 2 & 16,93 & $0: 34$ & $08: 34$ & $08: 44$ & $0: 44$ & 1890 & 255,41 & 27 \\
\hline Destination 3 & 17,71 & $0: 37$ & $08: 47$ & $08: 57$ & $0: 57$ & 3360 & 454,05 & 48 \\
\hline $\begin{array}{l}\text { The source } \\
\text { location }\end{array}$ & 35,86 & $1: 17$ & 09:37 & & $1: 37$ & 3360 & 454,05 & 48 \\
\hline
\end{tabular}




\begin{tabular}{|c|c|c|c|c|c|c|c|c|}
\hline \multirow{3}{*}{$\begin{array}{l}\text { Vehicle: } \\
\begin{array}{l}\text { Location } \\
\text { name }\end{array}\end{array}$} & \multirow{3}{*}{$\begin{array}{l}\text { V3 } \\
\begin{array}{l}\text { Distance } \\
\text { travelled }\end{array}\end{array}$} & \multirow{3}{*}{\begin{tabular}{|l} 
Stops: \\
$\begin{array}{l}\text { Driving } \\
\text { time }\end{array}$ \\
\end{tabular}} & \multirow{3}{*}{$\begin{array}{l}3 \\
\begin{array}{l}\text { Arrival } \\
\text { time }\end{array}\end{array}$} & \multirow{3}{*}{$\begin{array}{l}\text { Net } \\
\text { profit: } \\
\begin{array}{l}\text { Departure } \\
\text { time }\end{array}\end{array}$} & \multicolumn{3}{|c|}{ 3221,59 HRK (435,35 EUR) } & \multirow{3}{*}{ Load } \\
\hline & & & & & \multirow{2}{*}{$\begin{array}{l}\text { Working } \\
\text { time }\end{array}$} & \multicolumn{2}{|c|}{ Profit collected } & \\
\hline & & & & & & HRK & EUR & \\
\hline $\begin{array}{l}\text { The source } \\
\text { location }\end{array}$ & 0,00 & 0:00 & & 08:00 & 0:00 & 0 & 0 & 0 \\
\hline Destination 5 & 17,48 & $0: 36$ & $08: 36$ & $08: 46$ & $0: 46$ & 1680 & 227,03 & 24 \\
\hline Destination 7 & 21,98 & $0: 52$ & 09:02 & 09:12 & $1: 12$ & 3290 & 444,59 & 47 \\
\hline $\begin{array}{l}\text { The source } \\
\text { location }\end{array}$ & 44,31 & $1: 44$ & $10: 04$ & & $2: 04$ & 3290 & 444,59 & 47 \\
\hline
\end{tabular}

\begin{tabular}{|c|c|c|c|c|c|c|c|c|}
\hline \multirow{3}{*}{$\begin{array}{l}\text { Vehicle: } \\
\begin{array}{l}\text { Location } \\
\text { name }\end{array}\end{array}$} & \multirow{3}{*}{$\begin{array}{l}\text { V4 } \\
\begin{array}{l}\text { Distance } \\
\text { travelled }\end{array}\end{array}$} & \multirow{3}{*}{\begin{tabular}{|l} 
Stops: \\
$\begin{array}{l}\text { Driving } \\
\text { time }\end{array}$
\end{tabular}} & \multirow{3}{*}{$\begin{array}{l}3 \\
\text { Arrival } \\
\text { time }\end{array}$} & \multirow{3}{*}{$\begin{array}{l}\begin{array}{l}\text { Net } \\
\text { profit: }\end{array} \\
\begin{array}{l}\text { Departure } \\
\text { time }\end{array}\end{array}$} & \multicolumn{3}{|c|}{ 3499,94 HRK (472,96 EUR) } & \multirow{3}{*}{ Load } \\
\hline & & & & & \multirow{2}{*}{$\begin{array}{l}\text { Working } \\
\text { time }\end{array}$} & \multicolumn{2}{|c|}{ Profit collected } & \\
\hline & & & & & & HRK & EUR & \\
\hline $\begin{array}{c}\text { The source } \\
\text { location }\end{array}$ & 0,00 & $0: 00$ & & 08:00 & $0: 00$ & 0 & 0 & 0 \\
\hline Destination 6 & 22,09 & $0: 48$ & $08: 48$ & $08: 58$ & $0: 58$ & 2310 & 312,16 & 33 \\
\hline Destination 4 & 23,85 & $0: 56$ & 09:06 & $09: 16$ & $1: 16$ & 3570 & 482,43 & 51 \\
\hline $\begin{array}{l}\text { The source } \\
\text { location }\end{array}$ & 45,38 & $1: 44$ & $10: 04$ & & $2: 04$ & 3570 & 482,43 & 51 \\
\hline
\end{tabular}

\subsection{Comparative Analysis of the Results}

By comparing the two used methods, the Nearest Neighbor Heuristics and the VRP Spreadsheet Solver optimization program, it can be concluded that one method has proven

to be more effective in finding the optimal solution than the other. Table 9 shows a comparison of the results obtained for the Monday and Wednesday routing examples. The net profits of the routes obtained and the number of vehicles engaged are shown.

Table 9

Comparison of the Results Obtained for the Methods Used

\begin{tabular}{|c|c|c|c|c|c|c|}
\hline & \multicolumn{3}{|c|}{ Nearest Neighbour Heuristics } & \multicolumn{3}{|c|}{ VRP Spreadsheet Solver } \\
\hline & \multicolumn{2}{|c|}{ Net profit } & \multirow{2}{*}{ Number of vehicles } & \multicolumn{2}{|c|}{ Net profit } & \multirow{2}{*}{ Number of vehicles } \\
\hline & HRK & EUR & & HRK & EUR & \\
\hline Monday & 7583,66 & 1024,82 & 3 & 7587,01 & 1025,27 & 3 \\
\hline Wednesday & 13536,38 & 1829,24 & 5 & 13601,17 & 1838 & 4 \\
\hline
\end{tabular}


As shown in Table 9, the route optimizer gave better results than the Nearest Neighbor's handmade heuristic method. In the first example for determining routes on Monday, the results are about the same. The difference in cost is $3,35 \mathrm{HRK}(0,45 \mathrm{EUR})$ and the number of vehicles is the same, but in the example for Wednesday the profit is higher by $64,8 \mathrm{HRK}(8,76 \mathrm{EUR})$ for metaheuristics because it is by $41,96 \mathrm{~km}$ less and one vehicle less was used, which is an even greater saving because the budget did not use fixed vehicle costs, as well as driver costs, which are higher with more vehicles.

Of the two methods used, the VRP Spreadsheet Solver software has been shown to perform better than the Nearest Neighbor Heuristics, although the latter in some cases provides a satisfactory solution that, despite a different route and vehicle layout, is qualitatively and quite close to optimal.

\section{Conclusion}

In this paper, a mathematical model was set up on a real-life example of the business of a reverse distribution company after defining a transport problem where metaheuristic methods were applied to solve the problem of routing vehicles in the transport network. The purpose of applying mathematical methods is to reduce transportation costs by optimizing routes and the number of vehicles. Minimizing transportation costs brings savings and increases profits for businesses, so great attention must be taken in organizing transportation.

For example, two metaheuristic methods were used to optimize routes and solve vehicle routing problem - the Nearest Neighbor Heuristics method and several methods within the VRP Spreadsheet Solver software. The analysis of the results shows that the software tool performs better than using the second method in the form of less traveled distance, less engaged vehicles and ultimately lower delivery costs, which can lead to higher profit or decrease in the overall price of the service or product.

The application of software tools for solving vehicle routing problem greatly facilitates decision making in the logistics sector. The role of mathematical methods and software tools will be increasing with the further development of logistics and transportation technology, which will greatly facilitate the work of logistics operators in their daily work in the transport system. The number of logistic processes on the transport network that directly affect the utilization of the transport network, will be reduced.

\section{References}

Belfiore, P.; Yoshizaki, H.T.Y. 2009. Scatter Search for a Real-Life Heterogeneous Fleet Vehicle Routing Problem with Time Windows and Split Deliveries in Brazil, European Journal of Operational Research 199(3): 750-758.

Buntak, K.; Grgurević, D.; Drožđek, I. 2012. Međusobni odnos logističkih i transportnih sustava [In English: Interrelation of logistics and transport systems]. Tehnički glasnik 6(2): $228-232$.

Carić, T. 2004. Optimizacija prometnih procesa [In English: Optimization of Traffic Processes]. Faculty of Transport and Traffic Sciences, Zagreb, Croatia.

Čolić, P. 2013. Raspoređivanje vozila u stvarnom vremenu uz pomoć genetskog programiranja [In English: Vehicle routing in real time with genetic programming]. Master Thesis, Faculty of Electrical Engineering and Computing, University of Zagreb, Croatia. 
Dantzig, G.B.; Ramser, J.H. 1959. The Truck Dispatching Problem, Management Science 6(1): 80-91.

Erdoğan, G. 2017. An open Source Spreadsheet Solver for Vehicle Routing Problems, Computers \& Operations Research 84: 62-72.

Galić, A. 2018. Rješavanje problema usmjeravanja vozila hibridnim staničnim evolucijskim algoritmom [In English: Solving the Vehicle Routing Problem Using Hybrid Cellular Evolutionary Algorithm]. PhD thesis, Faculty of Transport and Traffic Sciences, Zagreb, Croatia.

Hasle, G.; Kloster, O. 2007. Industrial Vehicle Routing. In: Hasle G., Lie KA., QuakE. (eds) Geometric Modelling, Numerical Simulation, and Optimization. Springer, Berlin, Heidelberg, 397-435.

Laporte, G. 2007. What you should know about the vehicle routing problem, Naval Research Logistics 54: 811-819.

Pašagić, H. 2003. Matematičke metode u prometu [In English: Mathematical methods in traffic]. Faculty of Transport and Traffic Sciences, Zagreb, Croatia.
Pavlić Skender, H.; Grčić Fabić, M. 2013. Logistički špediter $\mathrm{u}$ fokusu prometnog i gospodarskog sustava [In English: Logistics freight forwarder in the focus of the traffic and economic system]. Pomorski zbornik 47-48: 95-107.

Stanković, R.; Pašagić Škrinjar, J. 2015. Logistika i transportni modeli [In English: Logistics and transport models]. Faculty of Transport and Traffic Sciences, Zagreb, Croatia.

Toth, P.; Vigo, D. 2002. The Vehicle Routing Problem. Society for Industrial and Applied Mathematics, Philadelphia, 29-51.

Woxenius, J. 1997. Terminals - A Barrier For Intermodality? In Proceedings of the Nordic Transport Research's conference on Intermodal Freight Transport. 2223 September Ebeltoft, Denmark, 1-16.

Woxenius, J. 1998. Development of small-scale intermodal freight transportation in a systems context. PhD thesis, Department of Logistics Chalmers, Göteborg. 